\title{
Optimization of Phosphogypsum By-Production Using Orthophosphoric Acid as Leaching Solvent with DifferentTemperatures and Leaching Time Periods
}

\author{
Monther Abdelhadi ${ }^{1}$, Nafeth Abdelhadi ${ }^{2}$ \& Tayel El-Hasan ${ }^{3}$ \\ ${ }^{1}$ Department of Civil Engineering, American University of Madaba, Jordan \\ ${ }^{2}$ Department of Civil Engineering, Faculty of Engineering Technology, Al-Balqa Applied University, Jordan \\ ${ }^{3}$ Department of Chemistry, Faculty of Science, Mu'tah University, 61710, Al-Karak, Jordan \\ Correspondence: Nafeth Abdel Hadi, Department of Civil Engineering, Al Balqa Applied University, Jordan. Tel: \\ 962-796-501-832. E-mail: nafeth22@bau.edu.j
}

Received: March 15, 2018 Accepted: March 26, 2018 Online Published: May 4, 2018

doi:10.5539/esr.v7n2p28 URL: https://doi.org/10.5539/esr.v7n2p28

\begin{abstract}
Phosphoric acid production generates unavoidable calcium sulfate by product (i.e. phosphogypsum (PG)) that is usually disposed either within a nearby located gypsum stacking system. However nowadays this type of industry has been faced with two main problems; these are the formation of huge stockpiles of phosphogypsum that affects the environment due to the presence of harmful radiations that is emitted from the uranium. In addition it contains $\mathrm{P}_{2} \mathrm{O}_{5}>1.0 \mathrm{wt} \%$ and fluorine $>0.18 \mathrm{wt} \%$, which makes it not suitable for the cement industry. At the same time consuming large quantity of expensive sulphuric acid that becomes a hazardous waste material too. The production ratio of $\mathrm{PG}$ verses marketable $\mathrm{P}_{2} \mathrm{O}_{5}$ as acid in the world is high as much as 5 tons of $\mathrm{PG}$ are produced for each ton of $\mathrm{P}_{2} \mathrm{O}_{5}$; in Jordan the ratio is around 5.0 - 5.3 ton of $\mathrm{PG} /$ ton of $\mathrm{P}_{2} \mathrm{O}_{5}$ produced depending on the phosphate rock composition, which means a huge amount of PG will accumulate at the Fertilizer plant in Aqaba. The major advantages of using orthophosphoric acid as leaching solvent is the decreasing ratio of the residual materials verses marketable $\mathrm{P}_{2} \mathrm{O}_{5}$ to be $589 \mathrm{~kg} /$ ton of $\mathrm{P}_{2} \mathrm{O}_{5}$ produced. These results were obtained by utilizing the wet agitation leaching technique, compared with 5.0 - 5.3 ton of disposed PG/ton of $\mathrm{P}_{2} \mathrm{O}_{5}$ produced by Jordan Phosphate Mines Company Ltd., (JPMC). However, this alternative technique resulted in lower $\mathrm{P}_{2} \mathrm{O}_{5}$ extraction, but decrease in bulk of the residue. The disadvantage is the higher dissolution of calcium phosphate and thus considerable calcium well remain in solution.
\end{abstract}

Keywords: Phosphogypsum, Jordan, Sulpheric acid, Orthophosphoric acid, $\mathrm{P}_{2} \mathrm{O}_{5}$ extraction

\section{Introduction}

Jordan has huge reserves of phosphate deposits, the main deposits existed in the southern region of the country (Bender, 1974). The concentrations of trace elements such as $\mathrm{U}, \mathrm{V}, \mathrm{Cd}, \mathrm{Cr}$, and As are increasing from south to north, for example, U ranged from 40-60 mg/kg ((Jordanian Phosphate Mines Company, 1998) and 70-80 mg/kg) for samples from Esh-Shidyia and Al-Hisa mines (Khaled et al., 1990). (Ghosheh and Dodeen, 1993) had showed that other heavy metals and toxic elements in the Jordanian phosphate rocks are lower compared with several phosphate deposits from the world; this was reached by (Al-Hwaiti et al., 2001). Abed et al. 2008; found that potential toxic metals behaves as $\mathrm{P}$ and are enriched by a factor of more than 1.5 in the diammonium phosphate (DAP) compared with the input phosphorite. And that the trace metal content in the PG is very low. However, U sticks to the mineral francolite during upgrading of the ores, and behaves similar to $\mathrm{Ca}$ and $\mathrm{P}_{2} \mathrm{O}_{5}(\mathrm{Abed}, 2011)$.

The phosphate industry is one of the most contaminating sources to the environment, which contributes to soil; water and air pollution (Vandenhove, 2002). Al-Hisaphosphate mines are heavily affecting the particulate matter in the areas around the mines, Hamaiedah and El-Hasan, 2011). The utilization of effluent mine water from the Eshidiya phosphate mines in agricultural uses was investigated; it was categorized as $\mathrm{C}_{4} \mathrm{~S}_{1}-\mathrm{C}_{4} \mathrm{~S}_{2}$ type, which indicates that this water cannot be used for irrigation on any type of soil (Al-Hwiti et al. 2016). Similarly, Jiries et al. (2004)has investigated the effluent water from Al-Hisa and Al-Abyad mines. And found that it can be used for irrigation of salt-tolerant plants. 
According to the European Fertilizer Manufacturing Association (EFMA), there are two phosphoric acid production processes; the first, at temperature $70-80{ }^{\circ} \mathrm{C}$ that yields $26-32 \% \mathrm{P}_{2} \mathrm{O}_{5}$, and gives acid and dehydrated phase $\left(\mathrm{CaSO}_{4} \cdot 2 \mathrm{H}_{2} \mathrm{O}\right)$. The second, at temperature $90-110{ }^{\circ} \mathrm{C}$, which yields $40-52 \% \mathrm{P}_{2} \mathrm{O}_{5}$, and gives acid and Hemi hydrate phase $\left(\mathrm{CaSO}_{4} \cdot 1 / 2 \mathrm{H}_{2} \mathrm{O}\right)($ EFMA, 2000).

The most common technique that has been employed in the world for production of phosphoric acid from the phosphate rock comprises from reacting the phosphate rock with concentrated sulphuric acid solutions as in the following equation:

$$
\mathrm{Ca}_{3}\left(\mathrm{PO}_{4}\right)_{2}+3 \mathrm{H}_{2} \mathrm{SO}_{4}+2 \mathrm{H}_{2} \mathrm{O} \rightarrow 2 \mathrm{H}_{3} \mathrm{PO}_{4}+\mathrm{CaSO}_{4} \cdot 2 \mathrm{H}_{2} \mathrm{O} \text { (gypsum) }
$$

Contaminated gypsum which also known as $\mathrm{PG}, \mathrm{CaSO}_{4} \cdot 2 \mathrm{H}_{2} \mathrm{O}$ is formed as coproduced in the production of phosphoric acid by the wet- process. Unfortunately the ratio of $\mathrm{PG}$ verses marketable $\mathrm{P}_{2} \mathrm{O}_{5}$ as much as 5 tons of $\mathrm{PG}$ were produced for each ton of $\mathrm{P}_{2} \mathrm{O}_{5}$. This ratio is affected by the composition of the phosphate rock. In Jordan the ratio is around 5.0-5.3 ton of $\mathrm{PG} / 1.0$ ton $\mathrm{P}_{2} \mathrm{O}_{5}$ produced (JPMC, 2008).

Many environmental issues raised by such waste disposal problem, so it is estimated that over 40 million tons of PG was produced and accumulated in Aqaba area by Jordan Phosphate Mines Company Ltd., (JPMC) during the period $1982-2008$. The JPMC annual disposal is approximately 2.2 million tons of dehydrate PG and 1.0 million tons of hemi hydrate. The problem is accentuated by the fact that the PG, in most of the technologies employed in the wet-process production of phosphoric acid, contains a number of serious contaminants such as radioactivity due to the presence of uranium, fluoride, heavy metals besides sulphuric and phosphoric acids and their salts. The problem is further worsened by the large volume of PG pond water which is used in most plants for scrubbing pollutants. Whereas (Abed, 2011) suggested that Uranium is concentrated in the final phosphoric acid.

The PG is found to be radioactive due to the presence of naturally occurring uranium and radium in the phosphate ore (Dippel, 2004). Thus, PG is classified as a hazardous waste and is currently being disposed and stockpiled on sandy soil (Berish, 1990), (Azouazi et al., 2001) and (Dueñas et al., 2007). There are various storage processes of PG wastes, such as ocean disposal (Wissa, 2001), dry stacking on land, which is the common practice (EPA, 1999), and wet stacking on basins (Anon, 1998), as well as the use of PG as mine backfill disposal as suggested by (Dippel, 2004). (Al-Hwaiti et al.,2005) reported that trace elements in the PG stacks are stable with time, which indicates that trace elements were not leached from the stacks in any significant amount.

An associated problem is the production of sludge produced in the neutralization of gypsum pond water by liming. The sludge produced is another solid waste which is a mixture of complex compounds of phosphates and fluorides and is disposed of on the gypsum stacks.

Some technologies attempted at minimizing the pollutants in the PG. One of these attempts was used by (Nabulsi, 1999). He carried out several tests on specimens that were prepared from the PG in Jordan; the results showed that it can be used as a gypsum binder in the building industry. It can be also for producing precast units of low density and acceptable thermal insulation properties. However, the problem here is the radioactivity that still presents in the tested PG samples.

Other attempt was done by Industrial Chemistry Center in Royal Scientific Society, 1994.The team in the center prepared several samples from PG that brought from JPMC-Industrial Complex in Aqaba-Jordan and washing these samples up to five times using Tap water and sea waterto reduce the impurities that present in the tested PG samples such as $\mathrm{H}_{3} \mathrm{PO}_{4}, \mathrm{HF}, \mathrm{H}_{2} \mathrm{SO}_{4}$ and $\mathrm{P}_{2} \mathrm{O}_{5}$. The results of washing revealed that the $\mathrm{P}_{2} \mathrm{O}_{5}$ content decreased $13 \%$, but the $\mathrm{SO}_{4}$ increased in the tested samples.

(Abdelhadi et al., 2014) demonstrated experimentally the use of raw PG without treatment (heating) in cement production, which will eliminate a serious environmental source of pollution; besides, decreases the cost of cement production.

(Smadi et al., 1999) studied the behavior of the compressive strength of cement with different replacement ratios of purified (PG) and calcined temperature up to $900{ }^{\circ} \mathrm{C}$, he found an increasing trend in compressive strength which improved the initial and final setting time. (Bhadauria andThakare, 2006) utilized the PG wastes in cement additive as past or mortar in concrete; it was found that it is suitable for concrete in terms of workability and compressive strength. PG is also known worldwide for its applications as a binder or cement, (Gutt, 1978); Ouyang et al., 1978); (Ghafoori, 1986); (Akın \&Yesim, 2004); (Degirmenci, 2008); (Lysandrou\&Pashalidis, 2008); and (Yang et al., 2009).

Other possibilities exist, but as yet not considered economical, for example the production of sulphuric acid from the PG or use it in cement clinker. At the same time the expensive sulphuric acid raw material consumed will produce a large pile of waste material (e.g. PG) near the plant is considered as another problem facing the 
production of phosphoric acid by using the sulphuric acid and phosphate ore. The estimated amount of sulphuric acid that consumed is about 2.7 ton $/ 1.0$ ton of $\mathrm{P}_{2} \mathrm{O}_{5}$ produced. (Rabba, 1993) had carried out a metallurgical test work on the phosphate shale copper ore (Cambrian) at Wadi Khalid, at northern Wadi Araba region. He concluded that the most sufficient and economic acid should be used for extraction the copper and $\mathrm{P}_{2} \mathrm{O}_{5}$ from the ore is the phosphoric acid to avoid the formation of PG.

The aim of this research is to find alternative technique by using the orthophosphoric acid for leaching the Jordanian phosphate ore instead of sulphuric acid. Therefore, the main objective of this study is to estimate the maximum acid extractable percent of $\mathrm{P}_{2} \mathrm{O}_{5}$ from the phosphate oreto determine the amount of insoluble minerals in the phosphate ore by using various acids/water ratios, and to investigate the release of $\mathrm{P}_{2} \mathrm{O}_{5}$ with various temperatures and duration of leaching using orthophosphoric acid as solvent. In addition this work aimed to prevent the formation of huge amounts of $\mathrm{PG}$ rich in uranium, fluorine and $\mathrm{P}_{2} \mathrm{O}_{5}$.

\section{Sampling and Analytical methodology}

\subsection{Leaching Test:}

Nine representative samples prepared from the phosphate ore sample labeled as $\mathrm{Ph}-1$, each of $10 \mathrm{~g}$ in weight, ground to -20 microns. One representative sample from the phosphate ore $(\mathrm{Ph}-1)$ was digested with concentrated nitric perchloric solutions. The solutions were analyzed using an A.A.S. technique, different standards contain increasing amount of $\mathrm{P}_{2} \mathrm{O}_{5}$ were employed to analyze the digestion filtrates. This technique was performed to remove errors in $\mathrm{P}_{2} \mathrm{O}_{5}$ estimation of the samples due to dilution of solutions for analysis. Eight representative samples from the phosphate ore $(\mathrm{Ph}-1)$, each of $10 \mathrm{~g}$ in weight were previously ground to -20 microns. Four samples (IR-5, IR-6, IR-7 and IR-8) were leached with orthophosphoric acid (90\%concentration which contains $65.29 \% \mathrm{P}_{2} \mathrm{O}_{5}$ concentration), it should be noted that each $1.0 \mathrm{ml}$ of acid is equivalent to $1.75 \mathrm{~g} \mathrm{H}_{3} \mathrm{PO}_{4}(90 \% \mathrm{Conc})$. Two of them were performed at temperature of $30^{\circ} \mathrm{C}$ for 1.0 and 2.0 hours leaching time and the other two samples were treated at temperature $50^{\circ} \mathrm{C}$ for 1.0 and 2.0 hours leach times using magnetic stir techniques for agitating the phosphate components in the leach solutions, employing an acid strength of $17.5 \%$ phosphoric acid on a weight basis, the strength being equivalent to $10.0 \mathrm{ml}$ of acid per $100 \mathrm{ml}$ of solvent used for leaching. The remaining four samples (IR-1, IR-2, IR-3 and IR-4) were leached with concentrated sulphuric acid ( $90 \%$ Conc.). Two of them were performed at temperature of $30^{\circ} \mathrm{C}$ for 1.0 and 2.0 hours leach times and the other two samples were treated at temperature of $50^{\circ} \mathrm{C}$ for 1.0 and 2.0 hours leach times, utilizing an acid strength of $18.35 \%$ sulphuric acid on a weight basis, the strength being equivalent to $10 \mathrm{ml}$ of acid per $100 \mathrm{ml}$ of solvent used for leaching. It should be noted that each $1.0 \mathrm{ml}$ of acid is equivalent to $1.835 \mathrm{gm} \mathrm{H}_{2} \mathrm{SO}_{4}$. Samples of the leached solution were being taken at intervals of 1.0 and 2.0 hours for analysis.

\subsection{Agitation Experiment}

Twenty nine representative samples have been prepared from the phosphate ore sample numbered Ph-1 were treated using an acid strength of $100,150,200$ and $300 \mathrm{ml}$ of $\mathrm{H}_{3} \mathrm{PO}_{4}(90 \%$ conc.) $/ 1000 \mathrm{ml}$ of solutions. The samples were $100 \mathrm{gm}$ in weight each. Nine samples leached for a period of 1.0, 2.0 and 3.0 hours, were performed at atemperature of $30 \mathrm{C}^{\circ}, 50 \mathrm{C}^{\circ}$ and $80 \mathrm{C}^{\circ}$ using an acid strength of $100 \mathrm{ml}$ of $\mathrm{H}_{3} \mathrm{PO}_{4}(90 \%$ conc.) $/ 1000 \mathrm{ml}$ of solutions. Other nine samples were leached under similar conditions that used in the previous samples (similar weights, leach times and leaching temperature) but different in acid strengths. The acid strength that used was $150 \mathrm{ml}^{\circ} \mathrm{H}_{3} \mathrm{PO}_{4}$ (90\%conc.) $/ 1000 \mathrm{ml}$ of solutions. Six of the remaining nine samples were treated using a similar conditions that used in the previous eighteen samples but employing an acid strength of $200 \mathrm{ml}$ of $\mathrm{H}_{3} \mathrm{PO}_{4}(90 \% \mathrm{conc}$.) $/ 1000 \mathrm{ml}$ of solutions and 1.0 and employed a leaching time of 1.0 and 2.0 hours. The last three samples were leached for one hour at a temperature of $30 \mathrm{C}^{\circ}, 50 \mathrm{C}^{\circ}$ and $80 \mathrm{C}^{\circ}$ using an acid strength of $300 \mathrm{ml}$ of $\mathrm{H}_{3} \mathrm{PO}_{4} / 1000 \mathrm{ml}$ of solutions. The leach residue after each interval was analyzed by X.R.F and Calcimeter for $\mathrm{P}_{2} \mathrm{O}_{5}, \mathrm{CaO}$, other extractable elements and calcite respectively.

The chemical composition of PG was investigated through X-Ray Fluorescence analysis. It was done using the machine (XRF-Pioneer F4), manufactured by Broker at the labs of Natural Resources Authority (NRA), Amman. The machine comes with an attached 72-position sample changer. Pellets were made by fusing $0.8 \mathrm{~g}$ of sample powder and $7.2 \mathrm{~g}$ of L2B4O7 in Au/Pt crucible using a flexor machine (Leco 2000) for $3-4$ minutes at $1200^{\circ} \mathrm{C}$. The melt was poured in a mold and left to cool to form a glass disc; trace elements were analyzed. The machine was calibrated with international standards, particularly the Geological Survey of Japan (GSJ) geochemical standards (i.e., Japanese slate JS1-1 and JS1-2). The analytical error was within 5\%. Moreover, mineral constituents were determined using X-Ray Diffraction analysis. It was executed using the machine (XRD-Philips Expert MPD) at the labs of Natural Resources Authority (NRA), Amman. The samples were scanned between $2^{\circ}$ and $65^{\circ} 2 \theta$, using Ni-filtered Co K $\alpha$ radiation, $40 \mathrm{kV} / 40 \mathrm{~mA}$, divergent and scattering slits of $0.02^{\circ} \mathrm{mm}$, a receiving slit of 
$0.15 \mathrm{~mm}$, with stepping of $0.01^{\circ}$ and scanning speed of $3 \% \mathrm{~min}$.

\section{Results and Discussion:}

\subsection{Treatment of Phosphate Ore Using concentrated $\mathrm{H}_{2} \mathrm{SO}_{4}$ and $\mathrm{H}_{3} \mathrm{PO}_{4}$}

The results showed that the $\mathrm{P}_{2} \mathrm{O}_{5}$ extraction obtained from two samples that were treated at temperatures $30 \mathrm{C}^{\circ}$ and $50 \mathrm{C}^{\circ}$ was $89.6 \%$ and $93.05 \%$ in 1.0 hour of leaching, with an acid consumption of 851 and $877 \mathrm{~kg} \mathrm{H}_{2} \mathrm{SO}_{4} /$ ton of ore respectively. The calculated amounts of $\mathrm{H}_{2} \mathrm{SO}_{4}$ that consumed to produce 1.0 ton of $\mathrm{H}_{3} \mathrm{PO}_{4}$ (concentration 99.5\%) were 2.29 and 2.26 tons respectively. The chemical results obtained for the residue from X.R.F. analysis showed that it contained $30.0,29.94 \% \mathrm{CaO}$, and $42.54,43.26 \% \mathrm{SO}_{3}$, using these figures the amount of gypsum precipitated in the leach residue (PG) was estimated to be $91.37 \%$ and $92.97 \%$ of the residue weight which are equivalent to 16.33 and $16.37 \mathrm{~g}$ respectively, while the original weights of the ore samples that used in the tests were 10.0gr each, this increase in weight being due to the formation of gypsum inthe residual samples.

The $\mathrm{P}_{2} \mathrm{O}_{5}$ extraction obtained from the other two samples that were treated at temperatures $30 \mathrm{C}^{\circ}$ and $50 \mathrm{C}^{\circ}$ was $100 \%$ for both tested samples in 2.0 hours of leaching, with an acid consumption of 896 and $897 \mathrm{~kg} \mathrm{H}_{2} \mathrm{SO}_{4} /$ ton of ore respectively. The calculated amounts of $\mathrm{H}_{2} \mathrm{SO}_{4}$ that consumed to produce 1.0 ton of $\mathrm{H}_{3} \mathrm{PO}_{4}$ (concentration $99.5 \%$ ) were 2.15 and 2.16 tons respectively. From the analysis of the leach residue for $\mathrm{CaO}$ and $\mathrm{SO}_{3}$ that was 94.63 and $95.07 \mathrm{wt} \%$ respectively, these figures are equivalent to $15.85 \mathrm{gr}$ with $23 \%$ loss of ignition and $15.59 \mathrm{gr}$ weight with $21 \%$ loss of weight respectively. It should be noted that the original ore samples used in the tests were $10 \mathrm{gr}$ weight each, the increase in weight being due to the formation of gypsum in the residual samples.

It should be noted that the samples used in these tests were leached under similar conditions of the previous tests (similar weights, leaching temperature and acid strengths), but different in leaching time periods. The complete results of these tests are presented in Tables 1.

Table 1a. X.R.F analysis and leaching results of the Ph-1 samples utilizing $\mathrm{H}_{2} \mathrm{SO}_{4}$ and $\mathrm{H}_{3} \mathrm{PO}_{4}$

\begin{tabular}{|c|c|c|c|c|c|c|c|c|}
\hline 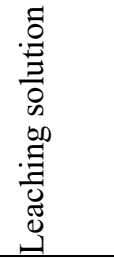 & $\begin{array}{l}\frac{o}{\tilde{a}} \\
\text { E్ } \\
\text { W }\end{array}$ & 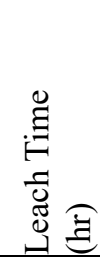 & 鞄 ठ & 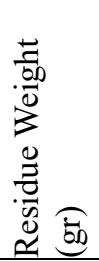 & $0_{0}^{0}$ & $\hat{O}_{\Omega^{n}}^{n} 0^{0}$ & $\stackrel{\ominus}{\infty} 0^{\circ}$ & $\sum_{i}^{\infty} 0^{0}$ \\
\hline \multirow[t]{4}{*}{$\mathrm{H}_{2} \mathrm{SO} 4$} & IR-1 & 1.0 & 30 & 16.33 & 30.0 & 1.92 & 3.63 & 0.04 \\
\hline & IR-2 & 2.0 & 30 & 16.75 & 29.4 & 0.00 & 4.00 & 0.04 \\
\hline & IR-3 & 1.0 & 50 & 16.37 & 29.94 & 1.28 & 3.68 & 0.03 \\
\hline & IR-4 & 2.0 & 50 & 16.4 & 30.8 & 0.00 & 3.5 & 0.00 \\
\hline \multirow[t]{4}{*}{$\mathrm{H}_{3} \mathrm{PO} 4$} & IR-5 & 1.0 & 30 & 4.93 & 38.91 & 23.27 & 14.43 & 0.34 \\
\hline & IR-6 & 2.0 & 30 & 3.85 & 40.31 & 23.87 & 13.41 & 0.34 \\
\hline & IR-7 & 1.0 & 50 & 4.00 & 41.8 & 24.10 & 12.26 & 0.25 \\
\hline & IR-8 & 2.0 & 50 & 3.21 & 42.37 & 25.45 & 11.11 & 0.18 \\
\hline \multicolumn{5}{|c|}{ XRF analysis of ore sample (Ph-1) } & 49.13 & 30.16 & 7.61 & 0.35 \\
\hline
\end{tabular}

Table1b.X.R.F analysis and leaching results of the Ph-1 samples utilizing $\mathrm{H}_{2} \mathrm{SO}_{4}$ and $\mathrm{H}_{3} \mathrm{PO}_{4}$

\begin{tabular}{|c|c|c|c|c|c|c|c|c|c|}
\hline 兑 & 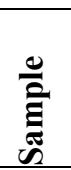 & 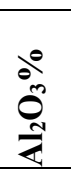 & $\begin{array}{l}\partial^{0} \\
0_{\tilde{N}}^{0} \\
\underline{I}\end{array}$ & 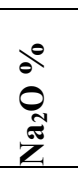 & $\begin{array}{l}0 \\
0 \\
0\end{array}$ & $\overbrace{0}^{0}$ & $\stackrel{\partial}{0}^{0}$ & 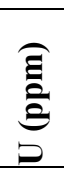 & ○ी \\
\hline \multirow{4}{*}{$\mathrm{H}_{2} \mathrm{SO} 4$} & IR-1 & 0.19 & 0.16 & 0.06 & 0.03 & 42.54 & 21.0 & 40 & 89.6 \\
\hline & IR-2 & 0.16 & 0.135 & 0.06 & 0.03 & 43.26 & 23.0 & NA & 100 \\
\hline & IR-3 & 0.14 & 0.137 & 0.05 & 0.02 & 43.26 & NA & 35 & 93.05 \\
\hline & IR-4 & 0.08 & 0.11 & 0.03 & 0.003 & 44.2 & 21.0 & NA & 100 \\
\hline \multirow{4}{*}{$\mathrm{H}_{3} \mathrm{PO} 4$} & IR-5 & 0.77 & 0.67 & 0.03 & 0.07 & 0.05 & 15.71 & 53 & 62.0 \\
\hline & IR-6 & 0.60 & 0.57 & 0.07 & 0.07 & 0.04 & 6.041 & 55 & 69.53 \\
\hline & IR-7 & 0.55 & 0.52 & 0.08 & 0.8 & 0.04 & & 48 & 68.4 \\
\hline & IR-8 & 0.51 & 0.46 & 0.07 & 0.07 & 0.04 & .5614 & 44 & 72.91 \\
\hline
\end{tabular}




\begin{tabular}{|l|l|l|l|l|l|l|l|l|}
\hline & & & & & & .30 & & \\
\hline $\begin{array}{l}\text { XRF analysis of } \\
\text { ore sample Ph-1 } \\
\text { sample (Ph-1) }\end{array}$ & 0.53 & 0.26 & 0.60 & 0.03 & 1.23 & 8.15 & & \\
\hline
\end{tabular}

\subsection{Treatment of Phosphate Ore Using $10.0 \mathrm{ml}$ of Concentrated $\mathrm{H}_{3} \mathrm{PO}_{4} / 90 \mathrm{ml}$ Distilled Water}

Leaching results have shown that $\mathrm{P}_{2} \mathrm{O}_{5}$ is released from phosphate using dilute orthophosphoric acid. The $\mathrm{P}_{2} \mathrm{O}_{5}$ extraction results obtained range from $62.0 \%$ using $10.0 \mathrm{ml}$ of $\mathrm{H}_{3} \mathrm{PO}_{4}(99.5 \%$ Conc.) $/ 100 \mathrm{ml}$ of solvent after 1.0 hour leaching to $69.53 \%$ using the same acid strength after 2.0 hours leaching at $30 \mathrm{C}^{\circ}$ Table (2). The maximum $\mathrm{P}_{2} \mathrm{O}_{5}$ extraction obtained from phosphate ore samples after 2.0 hours leaching at $50^{\circ} \mathrm{C}$ with orthophosphoric acid was $72.91-\%$. This was produced using acid solution of $10.0 \mathrm{ml} \mathrm{H}_{3} \mathrm{PO}_{4}(90 \%$ Conc.) $/ 100 \mathrm{ml}$ of solvent. Extraction from this material dropped to $68.04 \%$ when the lowest leach time periods were employed. Similarly, $\mathrm{CaO}$ extraction from the phosphate ore was also leach time periods dependent. The $\mathrm{CaO}$ and $\mathrm{P}_{2} \mathrm{O}_{5}$ extraction values obtained matched each other closely, indicating that all components of the apatite in the samples leached were being taken into solution. The calculated amounts of $\mathrm{H}_{3} \mathrm{PO}_{4}$ that generated from the tested samples after 2.0 hours leaching at $30^{\circ} \mathrm{C}$ and $50^{\circ} \mathrm{C}$ were 289.1 and $303.14 \mathrm{~kg}$ (concentration $100 \%$ ) $/ 1.0$ ton of phosphate respectively, while the generated phosphoric acid from the tested samples after 1.0 hour leaching at $30^{\circ} \mathrm{C}$ and $50^{\circ} \mathrm{C}$ were 257.8 and $282.9 \mathrm{~kg} /$ ton of ore respectively.

No precipitation was observed from the leach solutions once they were filtered, indicating that $\mathrm{CaO}$ and $\mathrm{P}_{2} \mathrm{O}_{5}$ were stable in the leached solutions. Weight losses in the residues were recorded for the four samples tested. These weight losses in the leached samples were related to the apatite and calcite content of the ore samples and the leach time periods employed. They varied from $50.70 \%$ at $30 \mathrm{C}^{\circ}$ to $60.0 \%$ at $50 \mathrm{C}^{\circ}$ after 1.0 hour leaching, while weight losses in the remaining two samples were ranged from 61.5 to $68.0 \%$ at $30 \mathrm{C}^{\circ}$ and $50 \mathrm{C}^{\circ}$ respectively after 2.0 hours leaching. The summary of the results of residue production, acid consumption and extracted $\mathrm{P}_{2} \mathrm{O}_{5} \%$ by using the two acids are presented in Tables $2 \mathrm{a}$ and $\mathrm{b}$.

Table 2a. Extracted $\mathrm{P}_{2} \mathrm{O}_{5}$ utilizing Sulphuric acid as the leaching solvent

\begin{tabular}{|c|c|c|c|c|c|c|c|c|c|}
\hline \multirow{2}{*}{\multicolumn{2}{|c|}{$\begin{array}{l}\text { Acids } \\
\text { Leach. } T^{\circ} \mathrm{C}\end{array}$}} & \multicolumn{8}{|c|}{$\mathrm{H}_{2} \mathrm{SO}_{4}$} \\
\hline & & \multicolumn{4}{|c|}{$30{ }^{\circ} \mathrm{C}$} & \multicolumn{4}{|l|}{$50{ }^{\circ} \mathrm{C}$} \\
\hline & & 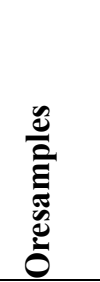 & 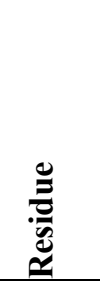 & 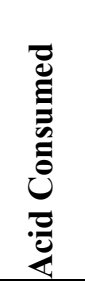 & 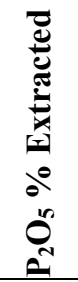 & 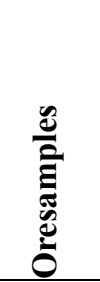 & 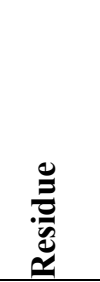 & 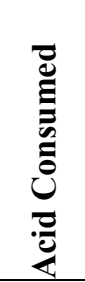 & 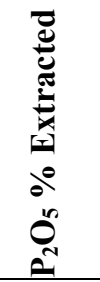 \\
\hline Leach. & 1 & 3.704 & 6.049 & 2.29 & 89.6 & 3.564 & 5.834 & 2.26 & 93.05 \\
\hline Time (hr) & 2 & 3.316 & 5.554 & 2.15 & 100 & 3.316 & 5.438 & 2.16 & 100 \\
\hline
\end{tabular}

Table 2b. Extracted $\mathrm{P}_{2} \mathrm{O}_{5}$ utilizing Orthophosphoric acid as the leaching solvent

\begin{tabular}{|c|c|c|}
\hline Acids & \multicolumn{2}{|c|}{$\mathrm{H}_{3} \mathrm{PO}_{4}$} \\
\hline Leach. $\mathrm{T}^{\circ} \mathrm{C}$ & $30^{\circ} \mathrm{C}$ & $50{ }^{\circ} \mathrm{C}$ \\
\hline
\end{tabular}




\begin{tabular}{|c|c|c|c|c|c|c|c|c|c|}
\hline & & 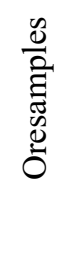 & 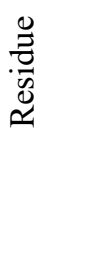 & 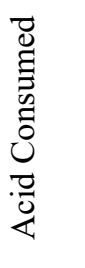 & 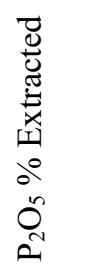 & 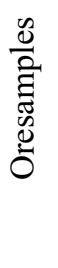 & 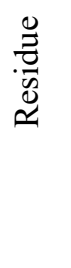 & 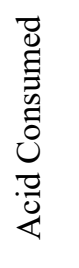 & 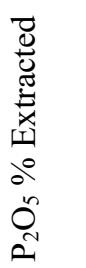 \\
\hline Leach. & 1 & 10 & 4.93 & 2.58 & 62.0 & 10 & 4.0 & 2.84 & 68.4 \\
\hline Time (hr) & 2 & 10 & 3.85 & 2.89 & 69.53 & 10 & 3.21 & 3.03 & 72.9 \\
\hline
\end{tabular}

Although the use of $\mathrm{H}_{3} \mathrm{PO}_{4}$ resulted in lower $\mathrm{P}_{2} \mathrm{O}_{5}$ extraction, but also reduces the residue weight Fig. 1.

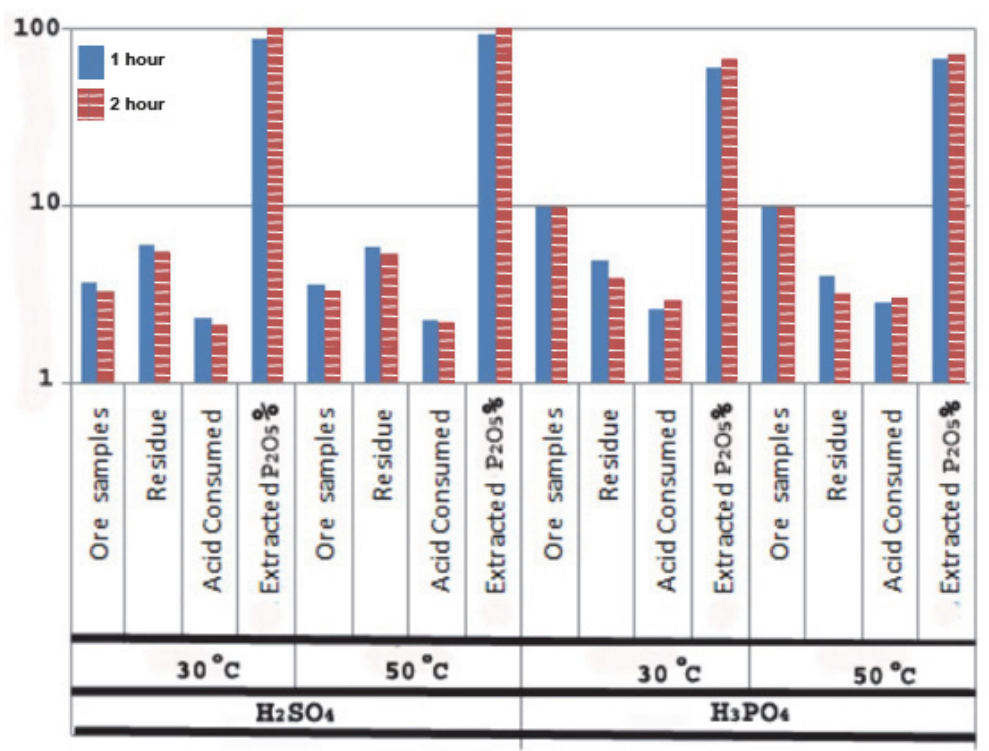

Figure 1. Agitation leaching test results using sulphuric and Orthophosphoric acid.

\subsection{Results Obtained Using Different Orthophosphoricacid/Tap Water.}

A total of 29 samples with weight $100 \mathrm{gr}$ were treated with different orthophosphoric acid $\left(\mathrm{H}_{3} \mathrm{PO}_{4}\right)$. Four acid/tap water ratios were performed (i.e. $100 \mathrm{ml} / 900 \mathrm{ml} ; 150 / 850 ; 200 / 800$ and $300 / 700$ respectively). Each mixture was investigated with variable temperature $\left(30 \mathrm{C}^{\circ}, 50 \mathrm{C}^{\circ}\right.$ and $\left.80 \mathrm{C}^{\circ}\right)$ and leaching time $(1,2$ and 3 hours). The results obtained are summarized in Tables $(3 \& 4)$.

Table 3a. X.R.F. analysis of the leached samples treated with various $\mathrm{H}_{3} \mathrm{PO}_{4}$ acid concentrations

\begin{tabular}{|c|c|c|c|c|c|c|c|c|}
\hline 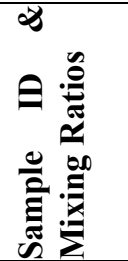 & & $\begin{array}{l}0 \\
0\end{array}$ & 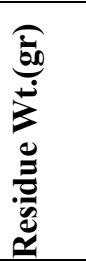 & 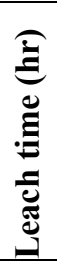 & 仓̊ & 巳̂ & $\begin{array}{l}0^{\circ} \\
\text { ô } \\
\text { in }\end{array}$ & 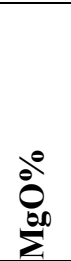 \\
\hline $100 / 900$ & $\begin{array}{l}\text { IR-9 } \\
\text { IR-10 } \\
\text { IR-11 } \\
\text { IR-12 } \\
\text { IR-13 } \\
\text { IR-14 }\end{array}$ & $\begin{array}{l}30 \\
30 \\
30 \\
50 \\
50 \\
50\end{array}$ & $\begin{array}{l}54.0 \\
46.0 \\
43.16 \\
46.34 \\
38.70 \\
32.5\end{array}$ & $\begin{array}{l}1.0 \\
2.0 \\
3.0 \\
1.0 \\
2.0 \\
3.0\end{array}$ & $\begin{array}{l}44.80 \\
42.7 \\
41.69 \\
45.71 \\
45.18 \\
44.50\end{array}$ & $\begin{array}{l}27.91 \\
27.60 \\
24.25 \\
29.38 \\
28.73 \\
27.58\end{array}$ & $\begin{array}{l}11.84 \\
13.74 \\
17.56 \\
11.39 \\
11.84 \\
13.96\end{array}$ & $\begin{array}{l}0.20 \\
0.15 \\
0.15 \\
0.19 \\
0.12 \\
0.10\end{array}$ \\
\hline
\end{tabular}




\begin{tabular}{|l|l|l|l|l|l|l|l|l|}
\hline & IR-15 & 80 & 44.5 & 1.0 & 32.08 & 13.00 & 39.18 & 0.30 \\
& IR-16 & 80 & 47.1 & 2.0 & 47.85 & 32.0 & 8.84 & 0.12 \\
& IR-17 & 80 & 64.0 & 3.0 & 48.18 & 35.20 & 6.53 & 0.13 \\
\hline $150 / 850$ & IR-18 & 30 & 28.4 & 1.0 & 37.72 & 19.62 & 23.08 & 0.20 \\
& IR-19 & 30 & 26.0 & 2.0 & 33.14 & 16.02 & 28.97 & 0.26 \\
& IR-20 & 30 & 25.3 & 3.0 & 30.97 & 12.64 & 29.15 & 0.29 \\
& IR-21 & 50 & 27.0 & 1.0 & 38.25 & 18.32 & 24.78 & 0.24 \\
& IR-22 & 50 & 24.1 & 2.0 & 34.22 & 15.00 & 27.80 & 0.18 \\
& IR-23 & 50 & 27.8 & 3.0 & 30.26 & 11.65 & 33.68 & 0.16 \\
& IR-24 & 80 & 37.5 & 1.0 & 45.21 & 29.0 & 12.74 & 0.09 \\
& IR-25 & 80 & 39.8 & 2.0 & 42.38 & 26.44 & 15.38 & 0.07 \\
& IR-26 & 80 & 38.8 & 3.0 & 41.92 & 26.23 & 14.79 & 0.08 \\
\hline 200/800 & IR-27 & 30 & 17.1 & 1.0 & 27.15 & 10.99 & 22.88 & 0.28 \\
& IR-28 & 30 & 16.8 & 2.0 & 30.55 & 9.90 & 17.87 & 0.24 \\
& IR-29 & 30 & 15.16 & 3.0 & 20.5 & 9.87 & 31.70 & 0.21 \\
& IR-30 & 50 & 15.73 & 1.0 & 27.33 & 9.33 & 25.15 & 0.27 \\
& IR-31 & 50 & 15.76 & 2.0 & 27.56 & 9.00 & 24.82 & 0.25 \\
& IR-32 & 50 & 14.66 & 3.0 & 20.60 & 10.0 & 34.40 & 0.27 \\
& IR-33 & 80 & 22.0 & 1.0 & 35.75 & 16.37 & 29.72 & 0.08 \\
& IR-34 & 80 & 24.0 & 2.0 & 34.95 & 17.38 & 30.83 & 0.02 \\
\hline & IR-35 & 30 & 20.3 & 1.0 & 23.7 & 15.86 & 19.82 & 0.16 \\
& IR-36 & 50 & 13.14 & 1.0 & 17.39 & 5.00 & 42.97 & 0.26 \\
& IR-37 & 80 & 11.8 & 1.0 & 11.7 & 3.28 & 59.5 & 0.25 \\
\hline 300/700
\end{tabular}

Table 3b. X.R.F. analysis of the leached samples treated with various $\mathrm{H}_{3} \mathrm{PO}_{4}$ acid concentrations

\begin{tabular}{|c|c|c|c|c|c|c|c|c|c|}
\hline 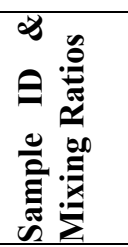 & & $\frac{e_{0}^{\circ}}{\overbrace{\pi}^{2}}$ & 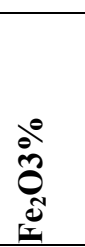 & $\begin{array}{l}\stackrel{0}{0} \\
\text { О̊ } \\
\text { Ż }\end{array}$ & $\begin{array}{l}\stackrel{0}{2} \\
\stackrel{2}{2}\end{array}$ & $\dot{\infty}_{0}^{\circ}$ & $e^{0}$ & ن. & 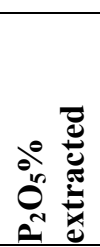 \\
\hline $100 / 900$ & IR-9 & 0.51 & 0.47 & 0.12 & 0.06 & ND & 5.60 & 7.62 & 50.03 \\
\hline & IR-10 & 0.55 & 0.54 & 0.24 & 0.07 & ND & 4.20 & 9.29 & 57.90 \\
\hline & IR-11 & 0.73 & 0.66 & 0.19 & 0.085 & ND & 4.80 & 9.11 & 65.30 \\
\hline & IR-12 & 0.43 & 0.48 & 0.49 & 0.075 & ND & 3.50 & 7.02 & 54.85 \\
\hline & IR-13 & 0.45 & 0.45 & 0.26 & 0.05 & ND & 4.94 & 7.05 & 63.00 \\
\hline & IR-14 & 0.49 & 0.44 & 0.17 & 0.05 & ND & 3.90 & 7.79 & 70.30 \\
\hline & IR-15 & 2.01 & 1.32 & 0.09 & 0.17 & ND & 3.30 & 5.76 & 80.82 \\
\hline & IR-16 & 0.13 & 0.12 & 0.39 & 0.02 & ND & 4.7 & 6.31 & 50.03 \\
\hline & IR-17 & 0.05 & 0.09 & 0.41 & 0.005 & ND & 4.2 & 5.38 & 25.3 \\
\hline $150 / 850$ & IR-18 & 1.03 & 0.83 & 0.22 & 0.11 & ND & 6.42 & 10.77 & 81.5 \\
\hline & IR-19 & 1.45 & 1.09 & 0.24 & 0.14 & ND & 7.00 & 12.26 & 86.2 \\
\hline & IR-20 & 1.49 & 1.07 & 0.13 & 0.13 & ND & 9.87 & 14.10 & 89.4 \\
\hline & IR-21 & 1.01 & 0.77 & 0.26 & 0.10 & ND & 7.86 & 9.74 & 83.6 \\
\hline & IR-22 & 1.30 & 1.00 & 0.15 & 0.11 & ND & 5.1 & 11.13 & 88.01 \\
\hline & IR-23 & 1.61 & 1.02 & 0.20 & 0.14 & ND & 3.4 & 15.7 & 89.26 \\
\hline & IR-24 & 0.20 & 0.11 & 0.43 & 0.05 & ND & 4.5 & 7.10 & 63.94 \\
\hline & IR-25 & 0.17 & 0.08 & 0.17 & 0.01 & ND & 4.3 & 11.07 & 65.11 \\
\hline & IR-26 & 0.22 & 0.09 & 0.41 & 0.04 & ND & 4.8 & 10.98 & 66.13 \\
\hline $200 / 800$ & IR-27 & 2.32 & 1.18 & 0.19 & 0.15 & 1.42 & 18.75 & 14.31 & 93.77 \\
\hline & IR-28 & 1.93 & 1.13 & 0.17 & 0.12 & 1.66 & 22.63 & 12.73 & 94.5 \\
\hline & IR-29 & 3.17 & 1.16 & 0.21 & 0.21 & 1.04 & 21.50 & 14.4 & 95.04 \\
\hline & IR-30 & 2.49 & 1.16 & 0.16 & 0.15 & 1.22 & 19.24 & 13.12 & 95.13 \\
\hline & IR-31 & 2.29 & 1.13 & 0.22 & 0.14 & 1.25 & 19.0 & 13.92 & 95.3 \\
\hline & IR-32 & 2.87 & 1.07 & 0.22 & 0.19 & 0.89 & 14.94 & 13.5 & 95.14 \\
\hline
\end{tabular}




\begin{tabular}{|l|l|l|l|l|l|l|l|l|l|}
\hline & IR-33 & 0.72 & 0.13 & 0.30 & 0.06 & 0.72 & 6.3 & 10.07 & 88.1 \\
& IR-34 & 0.56 & 0.09 & 0.24 & 0.05 & 0.6 & 5.2 & 10.09 & 86.17 \\
\hline $300 / 700$ & IR-35 & 2.13 & 1.10 & 0.13 & 0.14 & 1.32 & 15.04 & 20.18 & 89.33 \\
& IR-36 & 2.72 & 1.55 & 0.17 & 0.19 & & 15.0 & 12.18 & 98.0 \\
& IR-37 & 2.77 & 0.10 & 0.00 & 0.0 & 1.49 & 6.8 & 12.4 & 98.72 \\
& & & & & 1.18 & & & \\
\hline $\begin{array}{l}\text { XRF analysis of } \\
\text { headore ample (Ph-1) }\end{array}$ & 0.53 & 0.26 & 0.6 & 0.03 & 1.23 & 3.90 & 8.15 & - \\
\hline
\end{tabular}

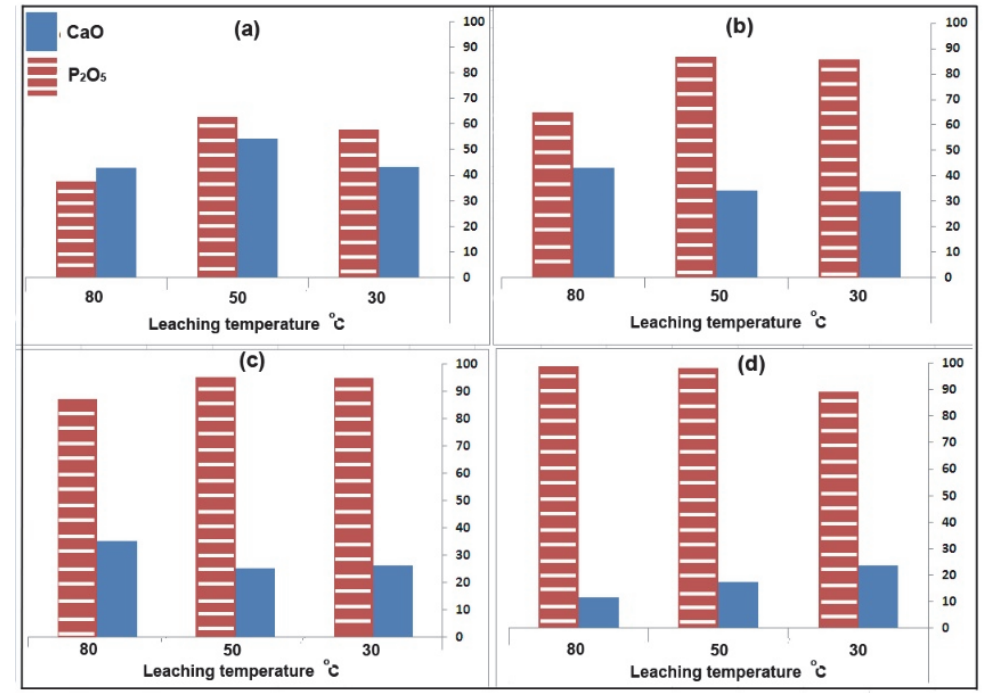

Figure 2. $\mathrm{CaO} \%$ accumulation and the extracted $\mathrm{P}_{2} \mathrm{O}_{5} \%$ at differentOrthophosphoric\%

Table 4a. Results of X.R.F. analysis for $\mathrm{CaO}$ of residue of leached samples with different $\mathrm{H}_{3} \mathrm{PO}_{4}$ acid strength

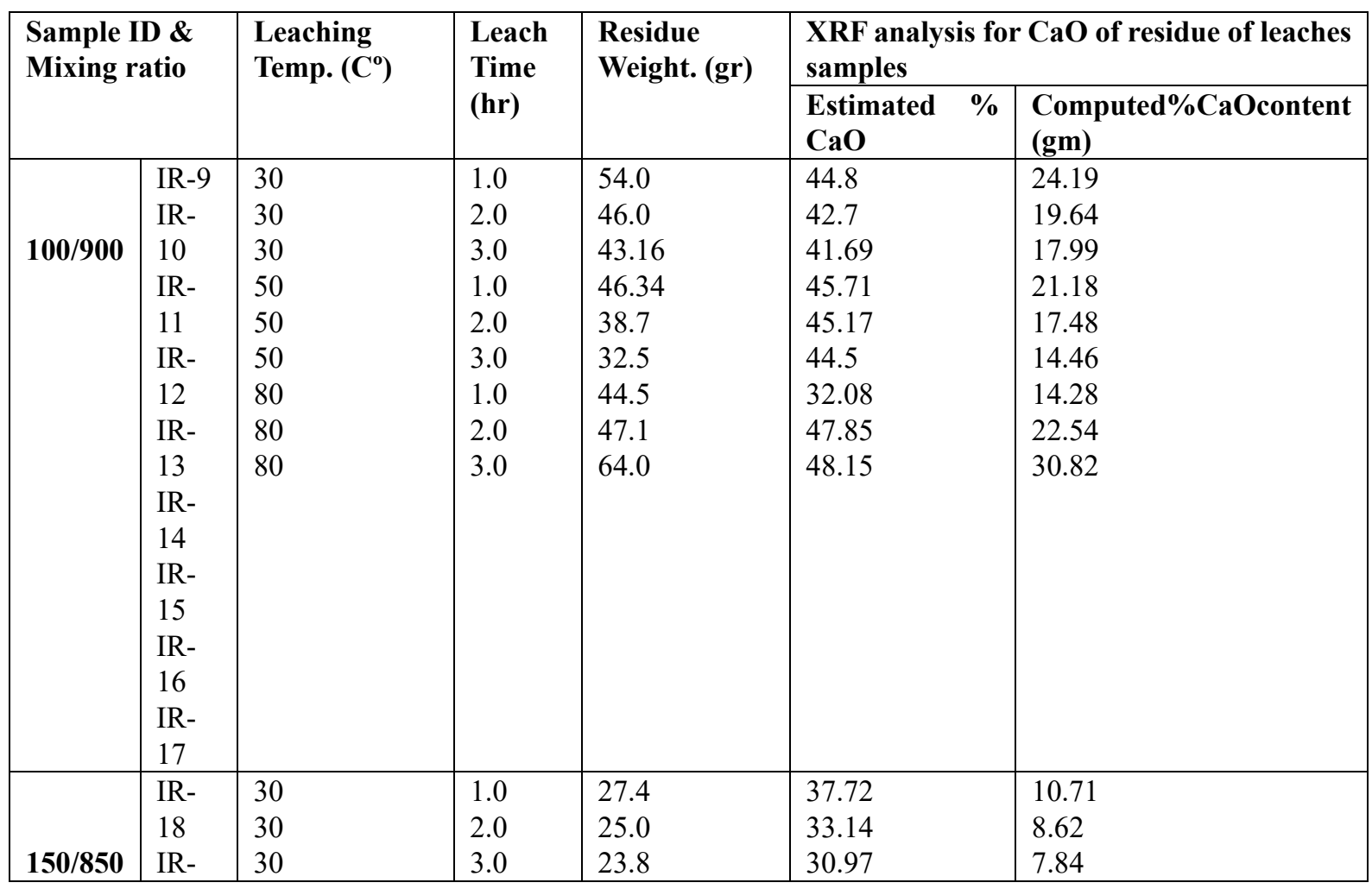




\begin{tabular}{|c|c|c|c|c|c|c|}
\hline & $\begin{array}{l}19 \\
\text { IR- } \\
20 \\
\text { IR- } \\
21 \\
\text { IR- } \\
22 \\
\text { IR- } \\
23 \\
\text { IR- } \\
24 \\
\text { IR- } \\
25 \\
\text { IR- } \\
26\end{array}$ & $\begin{array}{l}50 \\
50 \\
50 \\
80 \\
80 \\
80\end{array}$ & $\begin{array}{l}1.0 \\
2.0 \\
3.0 \\
1.0 \\
2.0 \\
3.0\end{array}$ & $\begin{array}{l}26.0 \\
23.1 \\
21.3 \\
37.5 \\
39.8 \\
38.8\end{array}$ & $\begin{array}{l}38.25 \\
34.22 \\
30.26 \\
45.21 \\
42.38 \\
41.92\end{array}$ & $\begin{array}{l}10.33 \\
8.25 \\
8.41 \\
16.95 \\
16.88 \\
16.26\end{array}$ \\
\hline \multirow[t]{2}{*}{$200 / 800$} & $\begin{array}{l}\text { IR- } \\
27 \\
\text { IR- } \\
28 \\
\text { IR- } \\
29 \\
\text { IR- } \\
30\end{array}$ & $\begin{array}{l}30 \\
30 \\
30 \\
50\end{array}$ & $\begin{array}{l}1.0 \\
2.0 \\
3.0 \\
1.0\end{array}$ & $\begin{array}{l}17.1 \\
16.8 \\
15.16 \\
15.73\end{array}$ & $\begin{array}{l}27.15 \\
30.55 \\
20.5 \\
27.33\end{array}$ & $\begin{array}{l}4.64 \\
5.13 \\
3.11 \\
4.3\end{array}$ \\
\hline & $\begin{array}{l}\text { IR- } \\
31 \\
\text { IR- } \\
32 \\
\text { IR- } \\
33 \\
\text { IR- } \\
34\end{array}$ & $\begin{array}{l}50 \\
50 \\
80 \\
80\end{array}$ & $\begin{array}{l}2.0 \\
3.0 \\
1.0 \\
2.0\end{array}$ & $\begin{array}{l}15.76 \\
14.66 \\
22.0 \\
24.0\end{array}$ & $\begin{array}{l}27.56 \\
20.6 \\
35.75 \\
34.95\end{array}$ & $\begin{array}{l}4.34 \\
3.02 \\
7.86 \\
8.39\end{array}$ \\
\hline $300 / 700$ & $\begin{array}{l}\text { IR- } \\
35 \\
\text { IR- } \\
36 \\
\text { IR- } \\
37\end{array}$ & $\begin{array}{l}30 \\
50 \\
80\end{array}$ & $\begin{array}{l}1.0 \\
1.0 \\
1.0\end{array}$ & $\begin{array}{l}20.3 \\
13.14 \\
11.8\end{array}$ & $\begin{array}{l}23.7 \\
17.39 \\
11.7\end{array}$ & $\begin{array}{l}4.81 \\
2.29 \\
1.38\end{array}$ \\
\hline
\end{tabular}

Table 4 b. X.R.F. analysis of the estimated and computed escaped $\mathrm{CO}_{2} \%$ and extracted $\mathrm{CaO} \%$ from the ore sample as obtained from the Calciminer analysis with various $\mathrm{H}_{3} \mathrm{PO}_{4}$ acid strength

\begin{tabular}{|c|c|c|c|c|c|}
\hline \multirow{2}{*}{$\begin{array}{l}\text { Sample } \\
\text { ID \& } \\
\text { Mixing } \\
\text { ratio }\end{array}$} & \multirow[t]{2}{*}{$\begin{array}{l}\text { Leaching } \\
\text { Temp. }\left(\mathbf{C}^{0}\right)\end{array}$} & \multicolumn{2}{|c|}{$\begin{array}{l}\text { Calcimeteranalysis for residues of } \\
\text { leached samples }\end{array}$} & \multirow[t]{2}{*}{$\begin{array}{l}\% \mathrm{CO}_{2} \text { escaped } \\
\text { from ore sample }\end{array}$} & \multirow[t]{2}{*}{$\begin{array}{l}\% \mathrm{CaO} \text { extracted } \\
\text { from ore sample }\end{array}$} \\
\hline & & $\begin{array}{l}\text { Estimated \% } \\
\mathrm{CO}_{2}\end{array}$ & $\begin{array}{l}\text { Computed } \mathrm{CO}_{2} \\
\text { content (gr) }\end{array}$ & & \\
\hline \multirow[t]{9}{*}{$100 / 900$} & IR-9 & 2.67 & 1.44 & 77.91 & 50.03 \\
\hline & IR-10 & 2.30 & 1.06 & 83.74 & 57.9 \\
\hline & IR-11 & 2.00 & 0.86 & 86.81 & 65.3 \\
\hline & IR-12 & 2.35 & 1.09 & 83.28 & 54.85 \\
\hline & IR-13 & 2.28 & 0.88 & 86.50 & 63.0 \\
\hline & IR-14 & 2.24 & 0.73 & 88.80 & 70.3 \\
\hline & IR-15 & ND & ND & ND & 70.94 \\
\hline & IR-16 & 2.26 & 1.06 & 83.74 & 54.13 \\
\hline & IR-17 & 2.79 & 1.79 & 72.55 & 37.24 \\
\hline \multirow[t]{2}{*}{$150 / 180$} & IR-18 & 1.35 & 0.37 & 94.33 & 78.20 \\
\hline & IR-19 & 0.96 & 0.24 & 96.32 & 83.46 \\
\hline
\end{tabular}




\begin{tabular}{|l|l|l|l|l|l|}
\hline & IR-20 & 0.59 & 0.14 & 97.85 & 84.05 \\
& IR-21 & 1.62 & 0.42 & 93.56 & 78.98 \\
& IR-22 & 1.39 & 0.32 & 95.10 & 83.21 \\
& IR-23 & 0.94 & 0.20 & 97.0 & 82.88 \\
& IR-24 & 2.59 & 0.97 & 85.12 & 65.49 \\
& IR-25 & ND & ND & ND & 65.67 \\
\hline $200 / 800$ & IR-26 & 2.40 & 0.93 & 85.74 & 66.89 \\
& IR-27 & 0.82 & 0.15 & 97.7 & 90.55 \\
& IR-28 & 0.74 & 0.12 & 98.16 & 89.55 \\
& IR-29 & 0.00 & 0.00 & 0.00 & 93.67 \\
& IR-30 & 0.7 & 0.11 & 98.31 & 91.25 \\
& IR-31 & 0.00 & 0.00 & 0.00 & 91.16 \\
& IR-32 & 0.00 & 0.00 & 0.00 & 93.85 \\
& IR-33 & 1.23 & 0.27 & 96.0 & 83.99 \\
& IR-34 & 1.33 & 0.32 & 95.1 & 82.93 \\
\hline $300 / 500$ & IR-35 & 0.89 & 0.18 & 97.24 & 90.21 \\
& IR-36 & 0.00 & 0.00 & 100.0 & 95.34 \\
& IR-37 & 0.00 & 0.00 & 100.0 & 97.2 \\
\hline
\end{tabular}

\section{Discussion}

\subsection{Results of the Agitation Leaching with Sulphuric Acid}

The calcium phosphate which may be dissolved during the leaching of phosphate ore with orthophosphoric acid is not necessarily a problem. The calcium may be precipitated by the addition of stoichiometric amounts of sulphuric acid and this correspondingly results in the increase of phosphoric acid in the leach solutions. The produced calcium sulphate is of an excellent quality and in itself represents a possible commercial product.

According to Table(2)each 1.0 ton $\mathrm{P}_{2} \mathrm{O}_{5}$ produced needs 3.52 ton of phosphate ore to produce 4.30 ton of precipitate with gypsum content about $98 \%$, this quantity of the produced gypsum will consume 1.96 ton of concentrated sulphuric acid as shown in Fig (1).

The estimated amount of residue (pure gypsum) for each 1.0ton of $\mathrm{P}_{2} \mathrm{O}_{5}$ produced was 0.626 ton, compared with 4.5-5.0 ton of PG residue produced by JPMC-IND COMPLEX in Aqaba/Jordan. The whiteness of the precipitated sample was measured, the results revealed that the whiteness was $97.5 \%$.Compared with 56.5 the whiteness of the PG that produced by JPMC-IND COMPLEX in Aqaba/Jordan.Furthermore, washing the precipitate with diluted sulphuric acidat a temperature of $40{ }^{\circ} \mathrm{C}$ for 10 minutes agitation will raise the gypsum mineral to more than $99.5 \%$ with $0.00 \% \mathrm{P}_{2} \mathrm{O}_{5}$ content. No impurities such as uranium and fluoride were recorded in the new product. Adding natural gypsum to this precipitate that washed by water with $1: 1$ ratio will reduce the $\mathrm{P}_{2} \mathrm{O}_{5}$ to $0.5 \%$ instead of $1.0 \%$ and raised $\mathrm{SO}_{4}$ in the new product. This will give the quality of the product to be more commercial and more suitable for cement industry and at the same time reduce the costs of washing the product by diluted sulphuric acid.

\subsection{Results of the Agitation Leaching with Orthophosphoric Acid}

The presence of apatite $\left(\mathrm{Ca}_{5}\left(\mathrm{PO}_{4}\right)_{3} . \mathrm{OH}, \mathrm{F}\right)$ in the Jordanian phosphate ore and its dissolution in the orthophosphoric acid solutions resulted in the presence of phosphor in solution. The form of the major reactions which occur during phosphate ore leaching are illustrated by the following equations:

- $\mathrm{Ca}_{5}\left(\mathrm{PO}_{4}\right)_{3}(\mathrm{OH}) \mathrm{F}+\mathrm{H}_{3} \mathrm{PO}_{4}+5 \mathrm{H}_{2} \mathrm{O} \rightarrow 5 \mathrm{CaO}+4 \mathrm{H}_{3} \mathrm{PO}_{4}+\mathrm{H}_{2} \mathrm{O}+\mathrm{F}$

- $\mathrm{Ca}_{5}\left(\mathrm{PO}_{4}\right)_{3}(\mathrm{OH}) \mathrm{F}+$ Phosphoric Acid + Water $\rightarrow$ Calcium oxide + Phosphoric Acid

- $5 \mathrm{CaO}+4 \mathrm{H}_{3} \mathrm{PO}_{4}+\mathrm{H}_{2} \mathrm{O} \rightarrow \mathrm{H}_{3} \mathrm{PO}_{4}+\mathrm{Ca}\left(\mathrm{H}_{2} \mathrm{PO}_{4}\right)_{2}$ (Mono-Calcium phosphate) Liquid

-Apatite $+\mathrm{H}_{3} \mathrm{PO}_{4}+\mathrm{SiO}_{2}+$ Fluorine $(\mathrm{F}) \rightarrow \mathrm{H}_{3} \mathrm{PO}_{4}+$ (Mono-Calcium phosphate) $+\mathrm{HF}(\mathrm{v})$

- $\mathrm{HF}(\mathrm{v})+\mathrm{SiO}_{2} \rightarrow \mathrm{Si} \mathrm{F}_{4}(\mathrm{v})$

- $\mathrm{Si} \mathrm{F}_{4}$ (v) + Scrubbing by water $\rightarrow \mathrm{H}_{2} \mathrm{SiF}_{6}$ (Liq.) Floro-silicic Acid

The other minor reactions that may be formed and resulted in formations of solid materials associated with the cake of residue samples. These reactions are:

1-Reaction between $\mathrm{Na}_{2} \mathrm{O}$ and $\mathrm{SiO}_{2}$ to produce Sodium silicates $\left(\mathrm{Na}_{2} \mathrm{SiO}_{3}\right)$

2-Reaction between $\mathrm{CaO}$ and $\mathrm{SiO}_{2}$ to produce Calcium silicates $\mathrm{Ca}_{2} \mathrm{SiO}_{3}$ 


\section{3-Reaction between $\mathrm{CaO}$ and $\mathrm{F}$ to produce Calcium fluoride $\mathrm{CaF}_{2}$}

Employing $10 \%$ ratio of solid to solution the leaching results have shown that $\mathrm{P}_{2} \mathrm{O}_{5}$ is released from phosphate ore samples using concentrated orthophosphoric acid (300 $\mathrm{ml}$ of $\mathrm{H}_{3} \mathrm{PO}_{4} / 1000 \mathrm{ml}$ of Tap water). The highest $\mathrm{P}_{2} \mathrm{O}_{5}$ extraction result obtained was $98.72 \%$ in 1.0 hour leaching time using a temperature of $80 \mathrm{C}^{\circ}$, comparing with $98.0 \%$ when employing a temperature of $50 \mathrm{C}^{\circ}$. Extraction of the $\mathrm{P}_{2} \mathrm{O}_{5}$ that obtained from this material dropped to $80.82 \%$ using a temperature of $80 \mathrm{C}^{\circ}$ and $54.85 \%$ at a temperature of $50 \mathrm{C}^{\circ}$ when the lowest acid strength $(100 \mathrm{ml}$ of $\mathrm{H}_{3} \mathrm{PO}_{4} / 900 \mathrm{ml}$ of Tap water) was employed, Table 3 .

Dissolution of the calcium phosphate content of the phosphate ore with orthophosphoric acid was mirrored by a weight loss of the leaching residue. This ranged from 46.0-88.20\% depending on the leaching time, acid concentration and temperature used in leaching process.

Using a temperature of $80^{\circ} \mathrm{C}$ for leaching the phosphate ore that employing 1.0 and 2.0 hour leaching periods, the weight loss recorded was lower compared with the previous tests that employed a temperatures of $30^{\circ} \mathrm{C}$ and $50^{\circ} \mathrm{C}$, this differences may be related to the amount of phosphate mineral formed in the residues of the leached samples that being treated at $80^{\circ} \mathrm{C}$ only. The extraction of $\mathrm{P}_{2} \mathrm{O}_{5}$ did not increase further even though the test was running for a period of 2.0 hours. However, residue weight continued to rise after 1.0 hour leaching. The result suggests that the extraction of $\mathrm{P}_{2} \mathrm{O}_{5}$ may be limited after 1.0 hour leaching at a temperature of $80^{\circ} \mathrm{Cand}$ strength of the acid that less than $30 \%$ is not capable of dissolving further $\mathrm{P}_{2} \mathrm{O}_{5}$ from the ore or even preventing the formation of calcium phosphate hydrate from the leach solutions at this temperature, Fig. (2).

Examining the leaching residues after 1.0 hour treatment using different acid concentration revealed that the main chemical differences observed between them is the $\mathrm{CaO}$ content. As the acid strength increased, it was observed that $\mathrm{CaO}$ values decreased in the residues. This was evident from the decrease in the residue weights Table 4 and Fig. (2).

It is interesting to note that in case of using an acid concentration of $200 \mathrm{ml} \mathrm{H}_{3} \mathrm{PO}_{4} / 800 \mathrm{ml}$ of water, the fluoride content in the leached ore sample that treated at $30 \mathrm{C}^{\circ}$ was $22.63 \%$ after 2.0 leaching time. However, the lowest fluoride extraction value $3.30 \%$ was noticed at the $100 \mathrm{ml} \mathrm{ml} \mathrm{H}_{3} \mathrm{PO}_{4} / 900 \mathrm{ml}$ leaching at $80{ }^{\circ} \mathrm{C}$. Generally the fluoride extraction is increasing with increasing acid concentration, and decreasing with increasing temperatures of leaching, thus $30^{\circ} \mathrm{C}$ yields always higher fluoride in residue in the form of fluorite mineral $\left(\mathrm{CaF}_{2}\right)$, as shown in Fig. (3).

Analysis of the leached samples revealed that in all cases the maximum extraction of fluorine was obtained after 2.0 hour from the tested samples that being used with acid strength of $200 \mathrm{ml}$ of phosphoric acid/ $800 \mathrm{ml}$ of solvent. It reaches $22.63 \mathrm{wt} \%$ at lower temperature $\left(30^{\circ} \mathrm{C}\right)$; meanwhile, the lowest fluorine extraction was found at $100 \mathrm{ml}$ of phosphoric acid $/ 900 \mathrm{ml}$ at higher temperature (i.e. $80^{\circ} \mathrm{C}$ ). There is a positive correlation to some extent between higher extraction of $\mathrm{P}_{2} \mathrm{O}_{5}$ and F; Table (3).

Employing 10\% ratio of solid to solution the leaching results have shown that $\mathrm{P}_{2} \mathrm{O}_{5}$ is readily released from phosphate ore samples using diluted orthophosphoric acid ( $200 \mathrm{ml}^{\circ} \mathrm{H}_{3} \mathrm{PO}_{4} / 800 \mathrm{ml}$ of solvent). The highest $\mathrm{P}_{2} \mathrm{O}_{5}$ extraction results obtained was $95.04 \%$ in 3.0 hours leaching time using a temperature of $30 \mathrm{C}^{\circ}$, comparing with $94.5 \%$ when employing a temperature of $30 \mathrm{C}^{\circ}$ and 2.0 hours leaching time. Consequently, we can conclude that employing a leaching temperature of $30 \mathrm{C}^{\circ}$ for 3.0 hours leaching time with acid strength $20 \%$ for leaching the phosphate ore, the extraction of $\mathrm{P}_{2} \mathrm{O}_{5}$ was $95.04 \%$ and this will remain constant even though an extra hour of leaching was added. This might be attributed to the fact that carbonate minerals (apatite and calcite minerals) in the phosphate ore sample were completely dissolved. This was confirmed by the absence of $\mathrm{CO}_{2}$ contents in the residue, Table (4). The remaining $5 \% \mathrm{P}_{2} \mathrm{O}_{5}$ in the residue could be presented in the form of crystalline phosphoric acid. Thus, no need for further use of higher acid strength or longer leaching time. It is interesting to note that the fluoride content in the leached ore sample that treated at $30 \mathrm{C}^{\circ}$ was $22.63 \%$ after 2.0 leaching. The decreases in extraction of fluoride may be due to the increase of fluorite mineral $\left(\mathrm{CaF}_{2}\right)$ formation in the residue sample which is estimated to be about $44.5 \%$ of the residue. X.R.D analysis for the leach residue of phosphate ore sample number IR-27(-2mm) that treated for 3.0 hour leaching at $30^{\circ} \mathrm{C}$ and acid strength of $200 \mathrm{ml} \mathrm{H}_{3} \mathrm{PO}_{4} / 800 \mathrm{ml}$ of water is shown in Figure (3).

Dissolution of the calcium phosphate content of the phosphate ore with orthophosphoric acid was mirrored by a weight loss of the leaching residue. This ranged from 82.0-84.84\% depending on the leach time used for leaching. 


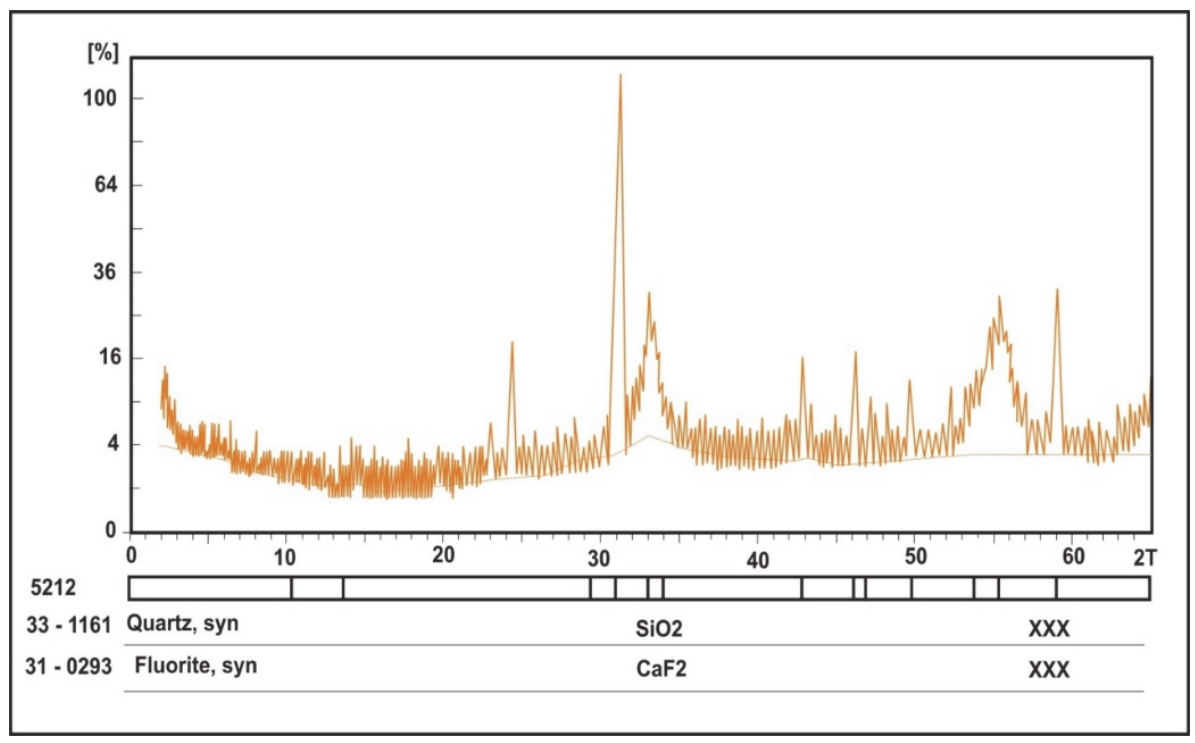

Figure 3. X.R.D analysis for the leach residue of phosphate ore sample number IR-27

\section{Conclusions}

In this work phosphoric acid has been investigated as a possible solvent for the recovery of $\mathrm{P}_{2} \mathrm{O}_{5}$ from Jordanian phosphate ores. The idea was initiated depending on bases that phosphoric acid composition is similar to the composition of the apatite phosphate mineral, so the acid will dissolve the apatite without any reaction between the dissolved components of the apatite and the phosphoric acid and no precipitations will be formed during the agitation leaching process as seen in the following equations:

$$
\mathrm{Ca}_{5}\left(\mathrm{PO}_{4}\right)_{3}(\mathrm{OH}) \mathrm{F}+\mathrm{H}_{3} \mathrm{PO}_{4}+5 \mathrm{H}_{2} \mathrm{O} \rightarrow 5 \mathrm{CaO}+4 \mathrm{H}_{3} \mathrm{PO}_{4}+\mathrm{H}_{2} \mathrm{O}+\mathrm{F}
$$

Apatite + Phosphoric Acid + Water $\rightarrow$ Calcium oxide + Phosphoric Acid

One of the assumed advantages in the use of orthophosphoric acid in leaching the phosphate ore would be pregnant solutions identical in acidic character which could be combined together for further treatment. The data confirms that $\mathrm{P}_{2} \mathrm{O}_{5}$ can be extracted from the Jordanian phosphate ores utilizing orthophosphoric acid solutions, and revealed the increase solubility of apatite in this solvent. The results show that dilute sulphuric acid was capable of leaching slightly more of all the elements measured under the leaching conditions employed at low temperature. Dissolution of the calcium phosphate content of the Jordanian phosphate ore with orthophosphoric acid caused a weight loss of the leaching residue ranged from 50.7-68.0 \% depending upon the leaching time.

\section{Acknowledgment}

The authors are grateful to the Department of laboratories at the Natural Resources Authority (NRA), Geoligist yousef Abu Salha and Geeologist Waddah Fares for their help and support in chemical and mineralogical analyses.

\section{References}

16-Dueñas, C., Liger, E., Cañete, S., Pérez, M., \&Bolívar, J.P. (2007). Exhalation of 222Rn from phosphogypsum piles located at the Southwest of Spain. Journal of Environmental Radioactivity, 95, 63-74.

Abdelhadi, N.A., Abdelhadi, M.A., \& El-Hasan, T. M. (2014). The Characteristics of Cement Mortars Utilizes the Untreated phosphogypsum Wastes Generated From Fertilizer Plant, Aqaba- Jordan. Jordan Journal of Earth and Environmental Sciences (JJEES), 6(2), 61-66.

Abed, A. (2011). Review of Uranium in the Jordanian Phosphorites: Distribution, Genesis and Industry. Jordan Journal of Earth and Environmental Sciences JJEES, 4(2), 35- 45.

Abed, A., Sadaqah, R., \& Al Kuisi, M. (2008). Uranium and Potentially Toxic Metals During the Mining, Beneficiation, and Processing of Phosphorite and their Effects on Ground Water in Jordan.Mine Water Environ, 27, 171-182.

Akın, A. I., \&Yesim, S. (2004). Utilization of weathered phosphogypsum as set retarder in Portland cement. Cement and Concrete Research, 34(4), 677-680. 
Al-Hwaiti, M. S., Brumsack, H. J., \& Schnetger, B. (February 2016). Suitability assessment of phosphate mine waste water for agricultural irrigation: an example from Eshidiya Mines, South Jordan. Environmental Earth Sciences. First online, 75, 276.

Al-Hwaiti, M., Carney, V., Ranville, J. F., \& Ross, P. E. (2005). Heavy Metal Assessment of phosphogypsum Waste Stockpile Material from Jordan. National Meeting of the American Society of Mining and Reclamation, 1923.

Al-Hwaiti, M., Gaunter, M., \& Saffarini, G. (April 2001). Geostatistical and geochemical investigation on Shidiya phosphorites western ore body, south Jordan: variation in ore composition and its content of toxic heavy metals available for plant absorption. In: Paper presented at the 7th Jordan geological conference, University of Jordan, Amman, 7-9.

Azouazi, M., Ouahibi, Y., Fakhi, S., Andres, Y., Abee, J. C. H., \& Benmansour, M. (2001). Natural radioactivity in phosphates, phosphogypsum and natural waters in Morocco. Journal of Environmental Radioactivity, 54, 231-242.

Batarseh, M., \& El-Hasan, T. (2009). Toxic Element Levels in the Phosphate Deposits of Central Jordan. Soil \& Sediment Contamination, 18, 205-215.

Beerbaum, B. (1977). Diagene der marine sedimentaren phosphate lay erstalle von Al-Hasa, Jordan, Germany.

Bender, F. (1974). Explanatory notes on the geological map of wadi Araba, Jordan. I:100000, 3 sheets. Geol Jahrb, $10,3-62$.

Berish, C. W. (1990). Potential environmental hazards of phosphogypsum storage in central Florida. In: Proceedings of the third international symposium on phosphogypsum, Orlando, FL, FIPR Pub. No. 01060083, 2, 1-29.

Bhadauria, S. S., \&Thakare, R. B. (2006). Utilization of phosphogypsum in cement mortar and concrete. 31st Conf. Our word in concrete and structures, Singapore.

Degirmenci, N. (2008). Utilization of phosphogypsum as raw and calcined material in manufacturing of building products. Construction and Building Materials, 22, 1857-1862.

Dippel, S. K. (2004). Mineralogical and geochemical characterization of phosphogypsum waste material and its potential for use as backfill at WMC Fertilizers' Mine site, Phosphate Hill, N-W Queensland. Master thesis, James Cook University. P336.

Dunham, R. J. (1962). Classification of Carbonate Rocks According to Depositional Texture. In, W.E. Hamm (Ed.), Classification of Carbonate Rocks, A Symposium. American Association of Petroleum Geologists, p. 108121.

El-Hasan, T. (2006). Geochemical dissociation of major and trace elements in bed and suspended sediment phases of the phosphate mines effluent water, Jordan. Environmental Geology (IF 0.678), 51(4), 621-629.

Environmental Protection Agency (EPA). 40 CFR Part 61. (1999). National emission standard for hazardous air pollutants; National Emission standards for Radon emissions from phosphogypsum stacks. Federal register, 64(2), 5574-5580.

European Fertilizer Manufacturers Association (EFMA). (2000). Production of Phosphoric Acid. Best Available Technique for pollution Prevention and control in the European Fertilizers Industry. Booklet No. 4, EFMA, Brussels, Belgium.

Ghafoori, N. (1986). Phosphogypsum based concrete: Engineering characteristics and road applications, Ph. D. thesis, University of Miami, Corel Gables, Florida.

Ghosheh, A., \& Dodeen, F. (1993). Heavy metals in Jordan phosphate rock. In: Proceedings of the 4th international fertilizer seminar, Amman p 36.

Hamaiedah, H., \& El-Hasan, T. (2011). Inorganic chemistry, granulometry and mineralogical characteristics of the dust fall over phosphate mine adjacent area, central Jordan. Environmental Earth Sciences, 62(8), 1771-1777.

Jiries, A., El-Hasan, T., Al-Hiwati, M., \& Seiler, K. P. (2004). Evaluation of the effluent water quality produced from phosphate mines in Central Jordan. Mine Water Environ, 23(3), 133-137.

Jordanian Phosphate Mines Company (JPMC). (1998). Annual Report for surveying and studying of water resources in the phosphate mines. Al-Shamil Engineering, Amman, p 167.

Khaled, H., \& Abed, A. (1980). Uranium in EshShidyia phosphates. Dirasat, 8(2), 57-66. Jordanian phosphate 
deposits. In: Paper presented at the 3rd Jordan geological conference, University of Jordan, Amman, 11-13 April 1990.

Lysandrou, M., \&Pashalidis, I. (2008). Uranium chemistry in stack solutions and leachates phosphogypsum disposed at a coastal area in Cyprus. Journal of Environmental Radioactivity, 99, 359-366.

Momani, E. (2011). Development of flotation scheme for fine Jordanian phosphate: physical and chemical evaluation $\&$ Froth flotation. Proceedings of $6^{\text {th }}$ Jordanian International Mining Conference. P33.

Nabulsi, B. (1999). Using phosphogypsum to produce gypsum cement pozzolana binders and thermal insulation materials. Royal Scientific Society. Amman-Jordan.

Ouyang, C., Nanni, A., \& Chang, W. (1978). Sulfate attack resistance of Portland cement mixtures containing phosphogypsum, Proceedings of Katherine and B. Mather International conference, Concrete durability,II, 100-102, American Concrete Institute, Detroit, 2007 - 2015.

Sadaqa, R, Abed, A., Grimm, K., \& Pufahl, P. (2001). Oxygen and carbon isotopes in the Jordanian phosphorites and associated fossils. In: Proceedings of the 7th Jordan geological conference (Book of abstracts), p81.

Smadi, M. M., Haddad, R. H., \& Akour, A. M. (1999). Potential use of phosphogypsum in concrete. Cement and Concrete Research, 29(9), 1419-1425.

Vandenhove, H. (2002). European sites contaminated by residues from the ore extracting and processing industries Int Congr. Ser., 1225, 307-315.

Wissa, A. E. Z. (2001). Phosphogypsum disposal \& the Environment. https://doi.org/http://www.ardaman.com/pubs/ phosphogypsum_disposal.htm. Acc. 13/09/2001

Yang, J., Liu, W., Zhang, L., \& Xiao, B. (2009). Preparation of load bearing building materials from autoclaved phosphogypsum. Construction and Building Materials, 23, 687-693. Retrieved from http://ardaman.com/waste.php3

\section{Copyrights}

Copyright for this article is retained by the author(s), with first publication rights granted to the journal.

This is an open-access article distributed under the terms and conditions of the Creative Commons Attribution license (http://creativecommons.org/licenses/by/4.0/). 